\title{
Potato bacterial wilt in Rwanda: occurrence, risk factors, farmers' knowledge and attitudes
}

\author{
Florence Uwamahoro ${ }^{1,2} \cdot$ Anna Berlin ${ }^{1} \cdot$ Charles Bucagu ${ }^{2} \cdot$ Helena Bylund $^{3} \cdot$ Jonathan Yuen $^{1}$
}

Received: 26 January 2018 / Accepted: 16 August 2018 / Published online: 22 September 2018

(C) The Author(s) 2018

\begin{abstract}
Potato is an important food commodity and efforts to increase its productivity should focus on addressing production limiting factors. Potato bacterial wilt (PBW) caused by Ralstonia solanacearum is one of the major constraints to potato production in Rwanda and no single method effectively controls the disease. Development of a sustainable management approach requires understanding of PBW distribution, risk factors, farmers' knowledge and management attitudes. Therefore, we surveyed PBW disease and interviewed farmers in eight districts of Rwanda during March-April 2015. We detected PBW in all the surveyed districts and it was ranked as the major potato disease constraint. Among districts, disease incidence and severity varied from 5 to $24 \%$ and 3 to $13 \%$, respectively, and was significantly higher in minor compared to major potato growing districts. Low PBW incidence and severity were associated with high altitude and low planting density, intercropping, crop rotation and avoidance of sharing farm tools. In all districts, farmers had little knowledge about PBW detection and spread, and the farmers' awareness of PBW management was often inconsistent with their practices. This incomplete knowledge about PBW was likely caused by inadequate extension services since most information about PBW was acquired from fellow farmers, parents or other relatives. Thus raising awareness of PBW and integrated disease management, including practices that are associated with low PBW, could limit the impact of this disease and help to secure food and income for potato growing farmers in Rwanda.
\end{abstract}

Keywords Solanum tuberosum $\cdot$ Ralstonia solanacearum $\cdot$ Potato farming $\cdot$ Awareness $\cdot$ Logistic regression $\cdot$ Potato brown rot

\section{Introduction}

Plants are essential for food security, or access to sufficient, affordable, safe and nutritious food for mankind (FAO 2017). They contribute directly to over $80 \%$ of the human diet (Bennett 2010). Plant pests and diseases cause damage to

Electronic supplementary material The online version of this article (https://doi.org/10.1007/s12571-018-0834-z) contains supplementary material, which is available to authorized users.

Florence Uwamahoro

florence.uwamahoro@slu.se

1 Department of Forest Mycology and Plant Pathology, Swedish University of Agricultural Sciences, Box 7026, 750 07 Uppsala, Sweden

2 Department of Crop Science, College of Agriculture Animal Sciences and Veterinary Medicine, University of Rwanda, Box 210, Musanze, Rwanda

3 Department of Ecology, Swedish University of Agricultural Sciences, Box 7044, 75007 Uppsala, Sweden crops, thus reducing the availability of and access to food, increasing the cost of food or resulting in changes to the traditional food preferences of populations (FAO 2017; Flood 2010). Food shortages and famines caused by plant diseases have been reported over the years (Zadoks 2008). Historical examples are: the Irish famine caused by potato late blight disease in which, subsequent to its introduction into the country in 1845 , killed more than one million people and caused 1.5 million people to leave their homeland (Strange 2003); Bengal famine caused by brown spot of rice from 1942 to 1943 through which two million people died in India (Sreenivasaprasad and Johnson 2001); and more recently, wheat blast in Bangladesh that caused up to $100 \%$ yield losses in the crop (Callaway 2016).

These kind of catastrophic plant diseases aggravate the current deficit of food supply in which about 800 million people are inadequately fed (Strange and Scott 2005). Estimated losses of 20 to $40 \%$ in crop production annually are reported and improved global food security requires solutions that address these losses i.e. improvement of plant health (Flood 2010; Savary et al. 2012). Hence, protection of plants 
and crops against plant diseases have an important role in meeting the growing demand for food quality and quantity (Strange and Scott 2005).

Potato (Solanum tuberosum) is the third most consumed food commodity worldwide after rice and wheat and has hence been recommended as a food security crop by the Food and Agriculture Organization of the United Nations (FAO) (Devaux et al. 2014). Potato provides more food much faster than any other major crop and is high in nutrient content (FAO 2008; Lutaladio and Castaldi 2009). Potato bacterial wilt (PBW) is among the top threats to the potato sector in developing countries and its control is among the prime research needs for farmers in sub-Saharan Africa and east and southeast Asia (Fuglie 2007). The disease was estimated to affect about 1.7 million hectares in approximately 80 countries worldwide, with global damage estimates of over USD 950 million each year (Birch et al. 2012).

Damage caused by the disease varies across countries and is certainly of significance in larger potato producing countries, compromising the attainment of household food selfsufficiency. Rwanda is one of the top five potato producing countries in Africa and the third in sub-Saharan Africa (Africa south of the Sahara desert), which is significant given the relatively small land size of the country (FAOSTAT 2015). Potatoes grow well in the whole country, from the highlands (major growing area) to the low and midlands (minor growing areas) (Munyemana and Oppen 2000). It is one of the six priority crops (potato, maize, rice, wheat, cassava and beans) supported in the Crop Intensification Program by the Ministry of Agriculture in Rwanda (Kathiresan 2011). Due to the growing market demand in Rwanda and neighbouring countries (USAID 2016), potato production has increased substantially, particularly in the Northern and Western provinces of Rwanda where agricultural conditions are favourable for potato production, reaching 700,000 t per year (MINAGRI 2014).

The average farm size in Rwanda is about 0.8 ha (Mpyisi et al. 2003) and individual holdings are fragmented into smaller parcels (Ali and Deininger 2015), hence potato growers are mainly smallholders (MINAGRI 2014). Muhinyuza et al. (2012) reported that about half of the total cultivated land is allocated to potatoes in the major potato growing highlands.

Under the Crop Intensification Program, farmers are encouraged to consolidate their land and decide to grow a crop that fits in their area among the priority crops in a synchronized fashion with the aim of improving productivity and sustainability (Kathiresan 2011). The program facilitates farmers' access to improved seeds and fertilizers and provides extension services on the use of inputs and improved cultivation practices. As a result, the average production of potato tripled from 2007 to 2011 and the yield increased from $7.8 \mathrm{t} / \mathrm{ha}$ to 10 t/ha between 2007 and 2009 (Kathiresan 2011).

The potato crop still faces several constraints, including low soil fertility, unavailability of clean (pathogen free) seeds, poor market accessibility and lack of financial investment, lack of access to high yielding varieties and a range of diseases (Muhinyuza et al. 2012). Potato bacterial wilt (PBW), also called potato brown rot, caused by Ralstonia solanacearum, was considered the second most important disease in potato production in Rwanda after late blight (caused by Phytophthora infestans) (Bicamumpaka and Haverkort 1983; Devaux et al. 1987; Scott 1988) but a recent study reported that, according to the farmers, the damage caused by PBW is more severe than those caused by late blight (Muhinyuza et al. 2012).

Ralstonia solanacearum is a globally distributed plant pathogen that affects over 200 species from more than 50 botanical families (Pasiecznik et al. 2005). The bacteria form a species complex and are subdivided into four phylotypes and further divided into sequevars (Fegan and Prior 2005). The strains in phylotype II sequevar 1 and phylotype II sequevar 2 (known historically and for quarantine purposes as Race 3 biovar 2 or R3bv2) are responsible for PBW (Cellier and Prior 2010). In addition to potato, R3bv2 also infects tomato, eggplant, geranium, many weeds and wild plants and can survive in surface water, soil, plant debris, and infected planting material (Mwankemwa 2015), which allows the pathogen to persist from season to season in the absence of host crops (Van Elsas et al. 2005).

Use of resistant cultivars could be the best option for managing PBW but no known varieties with resistance are available in Rwanda (REMA 2011). Some varieties such as Cruza 148 were found to have some degree of tolerance to PBW but may carry latent infections i.e. being infected by the pathogen without showing disease symptoms (French 1994). These features make the disease difficult to control and no single control method was found to be totally effective (Champoiseau et al. 2009). Potato crop losses between 50 and $100 \%$ due to PBW have been reported in Kenya (Muthoni et al. 2014a) and up to $75 \%$ in Australia (Stansbury et al. 2001).

Control strategies for PBW disease include the use of healthy seed and planting in uninfested soil, use of less susceptible varieties, rotation with non-host plants, cultural practices such as nematode control, sanitation and chemical control (Priou et al. 1999). An integrated strategy for these methods is recommended for reducing the incidence of bacterial wilt (Champoiseau et al. 2010; Martin and French 1985). Several studies have been conducted on the occurrence, spread and management of PBW in East Africa (Kurabachew and Ayana 2017; Kwambai et al. 2011; Lemaga et al. 2001; Lemaga et al. 2005; Muthoni et al. 2012; Muthoni et al. 2013; Muthoni et al. 2014a; 2014). Within the region, a number of efforts to control PBW have been made, but the disease remains devastating due to lack of healthy (or certified) potato seed, infested soils and lack of knowledge about disease management among farmers (Gikunda 2015). 
In Rwanda, reports of PBW are less recent (Bicamumpaka and Devaux 1984; Devaux et al. 1987; French 1994; Haverkort et al. 1984; Van der Zaag 1985) and information about disease occurrence, risk factors and farmers' knowledge is currently lacking or inadequate. The relationships between individual ways of life and their associated health risk problems have been demonstrated in public and crop health epidemiology (Breslow 1978; Willett 2002; Savary et al. 2011). Predictions of these risk factors help to prevent the disease and to guide research prioritization (Savary et al. 2011). The latter demonstrated that crop production situations represent very large risk factors for the occurrence of disease syndromes and that they are strong risk factors for individual diseases. Understanding the association of different risk factors with disease occurrence would help to identify the most important risks and focus efforts on developing an integrated and sustainable management package (Rusuku et al. 1997).

Acquisition of knowledge by farmers is the basis of the decision-making process regarding technological adoption. Farmers need to know about the existence of new technology, how to apply it, and what the outcomes are in terms of products, yield, potential environmental benefits, risks and costs. The information an individual has about a new technology forms the basis of the perceptions and attitudes this individual develops towards the technology (Meijer et al. 2015). In plant protection, attitudes are used as the farmers' practices or actual actions that farmers take to control their pest and disease problems (Oo et al. 2012).

This study aims at evaluating the extent or importance and knowledge of PBW disease in Rwanda as a basis to draw up control strategies. Specifically, this study was designed to (1) assess risk factors associated with PBW occurrence i.e. incidence and severity in Rwanda, (2) identify farmers' knowledge of PBW detection, spread and management, (3) evaluate the effectiveness of disease management attitudes by farmers and (4) investigate how information about PBW disease reaches farmers.

\section{Materials and methods}

\subsection{Selection of survey sites}

The survey of PBW was conducted during March-April, 2015 by a team of two enumerators skilled in agronomy and field surveys and a researcher with plant pathology skills. Survey sites were selected in four highland districts (Nyamagabe, Gicumbi, Musanze and Nyabihu) where potato is a major crop and in four midland districts (Huye, Rwamagana, Kayonza and Rulindo) where potato is grown but not as a major crop (Fig. 1). These districts vary in agro-ecological characteristics due to geophysical and climatic differences (Table 1). In each district, three locations were selected in consultation with district agriculture officers in order to reflect the production profile. At each location, five farms, each having at least 0.3 ha of potato under production were randomly selected. This criterion was used since at least a part of the potato production would be used for sale or trade. These farmers are mostly affected by crop production constraints because they grow potato not only to feed their families, but also to generate income to cater for other household needs. In total, 120 farms were selected for surveying and the household heads or family representatives interviewed. The household head is the person representing the people living together under one roof and eating from a common pot. In case the head was not available, another elder or responsible member of the household was interviewed.

\subsection{In-field bacterial wilt disease assessment}

At each of the selected farms, the survey team visited a potato field (the one closest to the farmer's home) to assess PBW incidence and severity and to determine the cropping system practiced by the farmers (Table 2). A geographical positioning system (GPS) unit was used to record the altitude, latitude and longitude coordinates of the farms at $3 \mathrm{~m}$ precision level. For a rapid field diagnosis, the visual symptoms of PBW (wilting symptoms) and streaming of milky white masses of bacterial cells (ooze) were used to confirm the presence of PBW caused by $R$. solanacearum (Priou et al. 1999).

Three quadrats (each measuring 10 by 10 plants, giving approximately 100 plants due to irregular planting patterns) were selected on a diagonal (one from the beginning and end of the diagonal and one from the middle). The PBW incidence was calculated for each field as the percentage of wilted plants over the total number of surveyed plants in the 3 quadrats. The severity for each of the surveyed plants was recorded based on a slightly modified 1-5 severity scale (Horita and Tsuchiya 2001), where $1=$ no symptom, 2 = one or two young leaves wilted, $3=$ half of the leaves wilted, $4=$ almost all the leaves wilted and $5=$ the whole plant was dead. The severity scale data were then transformed into percent wilted leaves, where scale $1=0 \%$ wilted leaves, $2=20 \%$ wilted leaves, $3=50 \%$ wilted leaves, $4=75 \%$ wilted leaves and $5=100 \%$ wilted leaves. The average percent wilted leaves for each field gave the percent severity of PBW for that field.

\subsection{Interviews}

The interviews were face to face with the respondent farmers and were performed in the local language (Kinyarwanda) by two enumerators and the researcher proficient in both English and Kinyarwanda. The questionnaire structure consisted of both open and closed questions (Creswell 2002). Closed questions included questions about cropping systems, cultural practices, 


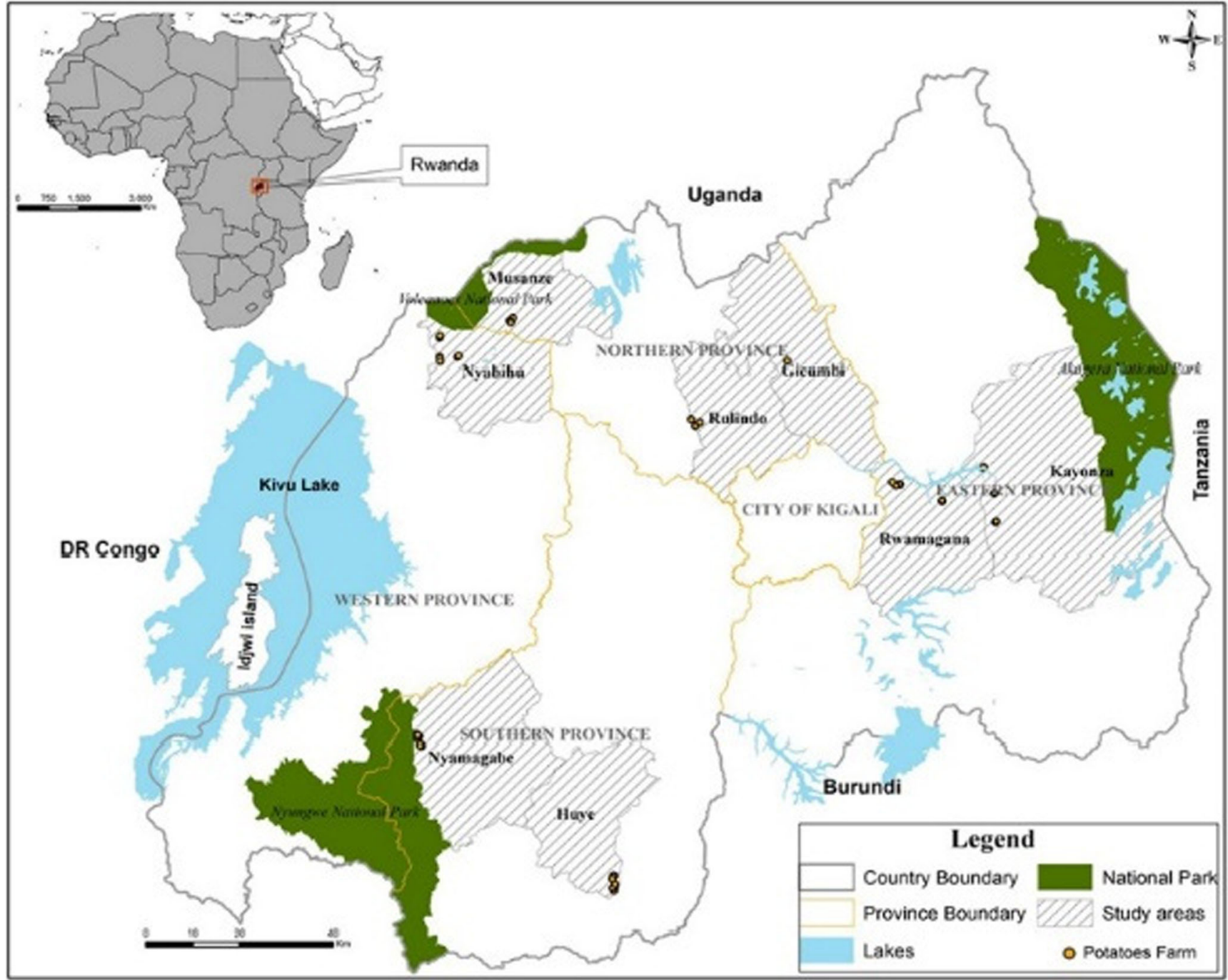

Fig. 1 Map of Rwanda showing surveyed districts and farms. Five farms per location, three locations per district and eight districts were surveyed $(n=$ 120)

Table 1 Importance of potato, altitude and climatic characteristics in the surveyed districts (RMA 2015; Verdoodt and Van Ranst 2006)

\begin{tabular}{lllll}
\hline Districts & Potato priority crop $^{\mathrm{a}}$ & $\begin{array}{l}\text { Altitude } \\
(\mathrm{masl})\end{array}$ & $\begin{array}{l}\text { Mean Temp } \\
\left({ }^{\circ} \mathrm{C}\right)\end{array}$ & $\begin{array}{c}\text { Rainfall } \\
(\mathrm{m} \mathrm{m} / \\
\text { year })\end{array}$ \\
\hline Nyamagabe & Yes & 1910 & 18.8 & 1438 \\
Huye & No & 1706 & 19.5 & 1244 \\
Rwamagana & No & 1535 & 20.8 & 1015 \\
Kayonza & No & 1581 & 20.2 & 1015 \\
Gicumbi & Yes & 2235 & 16.9 & 1178 \\
Rulindo & No & 1950 & 17.3 & 1326 \\
Musanze & Yes & 1878 & 17.7 & 1392 \\
Nyabihu & Yes & 2295 & 15.4 & 1263 \\
\hline
\end{tabular}

${ }^{a}$ Districts where potato is a priority crop under the Crop Intensification Program of the Ministry of Agriculture in Rwanda. The choice of priority crops per areas in Rwanda was based on the importance of the cultivated area and the farmers' opinions constraints related to pests and pathogens, PBW management practices as well as the source of acquired knowledge on PBW. This allowed only answers that fitted into categories that had been pre-set by the researcher. Open questions included farmers' knowledge about PBW detection, spread and management. Here, the respondents were allowed to answer in as much detail as they liked. To assess the source of knowledge on PBW awareness, the farmers were given a list of 15 possible sources (agronomists, brochures, extension officers, fellow farmers, local leaders, Ministry of Agriculture (MINAGRI), Newspapers, Non-Government Organizations (NGOs), parents or other relatives, posters, RAB (Rwanda Agriculture Board) scientists, radio, researchers, television and training) and they were asked to mention which sources provided them with knowledge of PBW detection, spread and management. The questionnaire form is provided in Supplementary material 1. 
Table 2 The risk factors by disease contingency table for logistic regression analysis of potato bacterial wilt in Rwanda

\begin{tabular}{|c|c|c|c|c|c|c|c|}
\hline \multirow[t]{2}{*}{ Risk factors } & \multirow[t]{2}{*}{ Categories $^{\mathrm{b}}$} & \multirow[t]{2}{*}{ No. farmers } & \multirow[t]{2}{*}{$\%$} & \multicolumn{2}{|c|}{ Incidence } & \multicolumn{2}{|c|}{ Severity } \\
\hline & & & & $\leq 10 \%$ & $>10 \%$ & $<7 \%$ & $\geq 7 \%$ \\
\hline \multirow[t]{2}{*}{ Altitude (masl) ${ }^{\mathrm{a}}$} & $1500-1900$ & 50 & 41.7 & 8 & 42 & 13 & 37 \\
\hline & $>1900 \mathrm{~m}$ & 70 & 58.3 & 54 & 16 & 56 & 14 \\
\hline \multirow[t]{3}{*}{ Cropping system $^{\mathrm{c}}$} & Mono & 39 & 32.5 & 7 & 32 & 9 & 30 \\
\hline & Mixed & 13 & 10.8 & 2 & 11 & 3 & 10 \\
\hline & Rotation & 68 & 56.7 & 53 & 15 & 57 & 11 \\
\hline \multirow[t]{3}{*}{ Grown varieties } & Indigenous & 35 & 29.2 & 9 & 26 & 13 & 22 \\
\hline & Improved & 49 & 40.8 & 43 & 6 & 45 & 4 \\
\hline & Composite & 36 & 30.0 & 10 & 26 & 11 & 25 \\
\hline \multirow[t]{5}{*}{ Source of seeds } & Own & 40 & 33.3 & 18 & 22 & 24 & 16 \\
\hline & Interhousehold & 26 & 21.7 & 4 & 22 & 5 & 21 \\
\hline & Certified & 31 & 25.8 & 30 & 1 & 30 & 1 \\
\hline & Market & 16 & 13.3 & 3 & 13 & 3 & 13 \\
\hline & Gov. & 7 & 5.8 & 7 & 0 & 7 & 0 \\
\hline \multirow{2}{*}{ Crop density } & $<30 \mathrm{~cm}$ & 51 & 42.5 & 6 & 45 & 12 & 39 \\
\hline & $\geq 30 \mathrm{~cm}$ & 69 & 57.5 & 56 & 13 & 57 & 12 \\
\hline \multirow[t]{2}{*}{ Sharing farm tools } & Yes & 74 & 61.7 & 23 & 51 & 27 & 47 \\
\hline & No & 45 & 37.5 & 39 & 6 & 41 & 4 \\
\hline
\end{tabular}

${ }^{\text {a }}$ masl, meters above sea level

${ }^{\mathrm{b}}$ Altitude: 1500 to $1900 \mathrm{masl}$ is the altitude for midland areas in Rwanda, $>1900$ masl is the altitude for highland areas. Source of seeds: Own, farm saved seeds; Interhousehold, Seeds sourced from other farmers; Gov., Seeds from the government institutions; Certified, Seeds from well-known multipliers; Market, Seeds bought from the local market either sold for seeds or food

${ }^{\mathrm{c}}$ Cropping system: Mono, mono-cropping: potato is grown in pure stand from season to season; Mixed, mixed cropping where potato is intercropped with other food or cash crops; rotation, potato is grown in pure stand and rotated with other crops after one or more seasons; Grown varieties: indigenous, varieties that the farmers had been growing in the same area for more than 10 years and that the farmers didn't renew the seeds; improved, varieties that were grown from newly adopted seeds provided by the Rwanda Agriculture Board (RAB) or known multipliers; Composite, is a mixture of both newly adopted varieties and indigenous in the same field

\subsection{Statistical analyses}

Mean comparisons of PBW incidence and district severity were calculated using one way ANOVA, multiple comparisons of the least significant difference (LSD) and adjusted $p$ values using the R package Agricolae (De Mendiburu 2015). Assessment of relationship between PBW disease and independent variables (altitude, cropping systems, grown varieties, source of seeds, crop density and sharing farm tools) was performed using logistic regression as described by Yuen et al. (1996) with R statistical software (R core team 2016).

Logistic regression calculates the probability of a given binary outcome (response) as a function of the independent variables (McCullagh and Nelder 1989). Hence, the data on disease incidence and severity were classified into separate categories of binomial qualitative data. In this case, the binary outcome was the probability that PBW incidence exceeds $10 \%$ and severity exceeds $7 \%$ in a given potato field. We selected class boundaries that divide data entries into approximately two equal classes (case and control). Categorized independent variables here refered to as the risk factors, and contingency tables built to represent the bivariate distribution of fields according to two classifications (e.g cropping systems by PBW disease incidence) are given in Table 2.
Logistic regression models allow evaluation of the importance of multiple independent variables that affect the response variable. In this case, the importance of the risk factors under study (Table 2) were evaluated in three ways (Fininsa and Yuen 2001). First, the association of each factor alone with PBW incidence or severity was tested in the regression model. Second, the association of each factor with PBW incidence or severity was tested when entered last into the model with all other factors. Third, factors with high association to PBW incidence or severity when entered first and last into a model were added to a reduced multiple factor model. A complete analysis of deviance table was generated for the final reduced multiple factor model, where deviance reduction was calculated for each factor as it was added to the reduced model.

Deviance was used to compare single and multiple factor models. The difference between the two models, known as likelihood ratio test (LRT), was used to examine the importance of each factor and was tested against a $\chi^{2}$ value (McCullagh and Nelder 1989) where the number of degrees of freedom in the $\chi^{2}$ value corresponds to the difference in degrees of freedom between the two models (Fininsa and Yuen 2001). 


\section{Results}

\subsection{Socio-economic characteristics of the respondent farmers}

The interviewed farmers consisted of both male $(58 \%)$ and female $(42 \%)$ household heads (Table S1). More than $70 \%$ of the households had 3 to 6 members. The majority of the household heads (61\%) were in the age range of 36 to 55 years, more than $75 \%$ were married and about $68 \%$ had completed primary education. The average land size owned by the households varied between 0.4 and 1.2 ha, while owned land under potato production ranged from 0.2 to 0.8 ha in different districts (Table S1), meaning that 50 to $60 \%$ of the farmers' total land was used for potato cultivation. The land under potato was much larger $(0.6-0.8 \mathrm{ha})$ in major potato growing districts than in moderate potato growing districts $(0.2-0.4 \mathrm{ha})$. Many of the household heads (above $45 \%$ ) had more than 20 years' experience of potato farming.

\subsection{Distribution of potato bacterial wilt}

The majority of farmers ( 80 to $100 \%$ ) reported PBW to be the major disease constraint to potato, faming followed by late blight reported by 0 to $73 \%$ of the respondents in the different districts. Only $13 \%$ of the farmers in the Gicumbi district reported no pest or disease constraints on their potato farms (Fig. 2).

Potato bacterial wilt was present in $86 \%$ of the surveyed potato farms (data not shown). Incidence and severity of PBW varied among farms, locations and districts. At the district level, the highest incidence (24\%) was recorded in Kayonza district while the lowest (5\%) was recorded in the
Gicumbi district (Table 3). The disease was significantly higher in minor potato growing districts compared to major potato growing districts, severity varying from 3 to $13 \%$ (Table 3).

\subsection{Risk factors associated with potato bacterial wilt incidence and severity}

Six factors viz. altitude, cropping system, grown variety, source of seeds, crop density and sharing of farm tools were tested and found to vary in association with PBW incidence and severity. All factors were significantly $(p<$ 0.0001) associated with PBW incidence and severity when entered alone in a logistic regression model. However, grown variety and seed source lost their significance when entered last into the model together with other factors (Table 4). Altitude, spacing (crop density) and sharing farm tools were the factors that remained highly significantly $(p<0.0001)$ associated with PBW incidence when entered first and last into the model $\left(\chi^{2}=46.99\right.$ and 22.16, $\mathrm{df}=1 ; \chi^{2}=62.50$ and $25.87, \mathrm{df}=1$ and; $\chi^{2}=46.99$ and $22.16, \mathrm{df}=1$ respectively). Similarly, altitude remained highly significant $(p<0.0001)$ in association with PBW severity in single and multiple models $\left(\chi^{2}=36.28\right.$ and 16.03, df=1).

The importance of altitude, cropping system, crop density and sharing of farm tools for PBW incidence and severity were tested in the reduced model. Analysis of deviance for these factors when added one by one to the reduced model revealed the importance of each factor and its categories. Parameter estimates resulting from the reduced regression model and their standard errors are shown in Tables 5 and 6.
Fig. 2 Major potato pests and diseases mentioned by the farmers in the surveyed districts $(\mathrm{n}=120)$

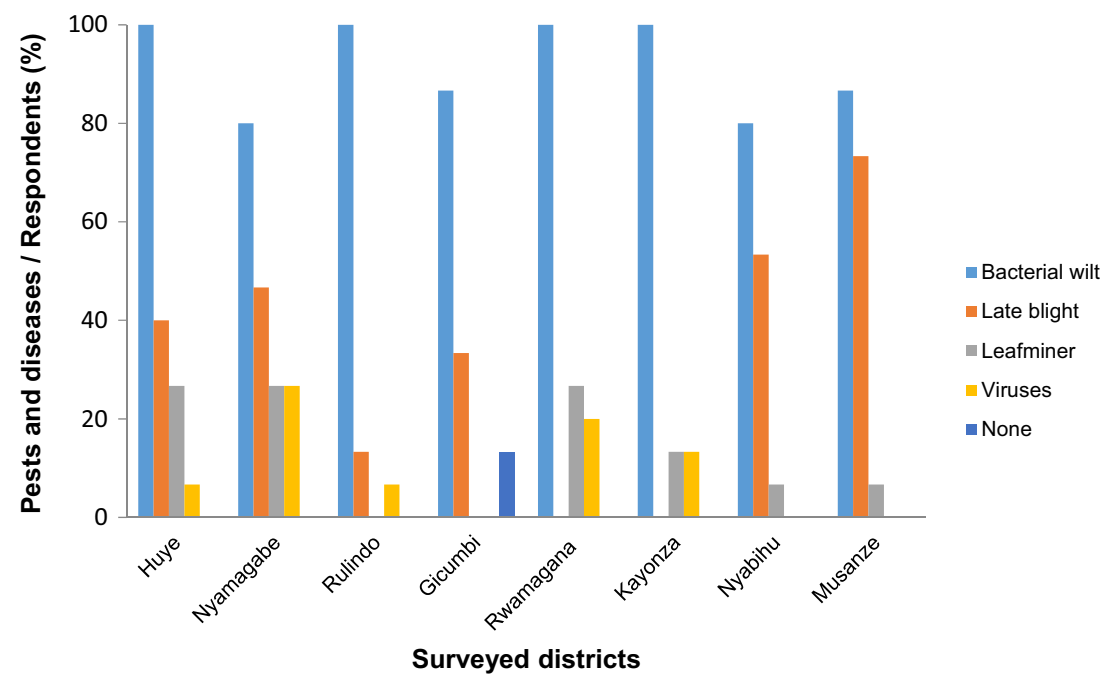


Table 3 Potato bacterial wilt disease incidence and severity in the surveyed districts of Rwanda ${ }^{\mathrm{e}}$

\begin{tabular}{lll}
\hline Districts & Incidence (\%) & Severity (\%) \\
\hline Kayonza & $24.4^{\mathrm{a}}$ & $13.1^{\mathrm{a}}$ \\
Huye & $16.7^{\mathrm{b}}$ & $8.1^{\mathrm{bc}}$ \\
Rwamagana & $16.6^{\mathrm{b}}$ & $9.9^{\mathrm{b}}$ \\
Rulindo & $14.1^{\mathrm{bc}}$ & $8.7^{\mathrm{b}}$ \\
Nyabihu & $8.6^{\mathrm{cd}}$ & $5.2^{\mathrm{cd}}$ \\
Musanze & $8.5^{\mathrm{d}}$ & $5.0^{\mathrm{cd}}$ \\
Nyamagabe & $6.1^{\mathrm{d}}$ & $3.7^{\mathrm{d}}$ \\
Gicumbi & $5.2^{\mathrm{d}}$ & $3.1^{\mathrm{d}}$ \\
\hline
\end{tabular}

${ }^{\mathrm{e}}$ Means that are followed by the same letters are not significantly different in incidence and severity of PBW $(p<0.05)$

High incidence and severity of PBW showed high probability of association with sharing of farm tools while low incidence and severity were highly associated with high altitude (>1900 masl), rotation and intercropping system as well as wide spacing ( $\geq 30 \mathrm{~cm}$ ) between plants (Tables 5 and 6 ). High altitude reduced PBW incidence and severity 100 and 26 fold, respectively, compared to medium altitude. Wide spacing reduced the incidence and severity by 50 and 5 fold, respectively, compared with dense spacing, while crop rotation reduced the probability of high incidence and severity by 16.7 fold compared to mono-cropping. Contrarily, sharing farm tools increased PBW incidence and severity by 28 and 15 fold, respectively, compared to not sharing tools.

\subsection{Farmers' awareness of PBW detection and spread methods}

Farmers were asked to mention as many methods as they knew for PBW detection, spread and management (Table S2). In all districts, PBW detection knowledge of the farmers was based on wilting of leaves (98\%) and tuber rot (45\%). A considerable proportion of the farmers (7 to 53\%) in major potato growing districts could correctly describe symptoms inside the stem and tubers such as; brown coloration in the stem, oozing in tuber eyes and a ring circle with ooze in cut tubers (Fig. 3). These symptoms were not known in minor growing districts. Only $2 \%$ of the farmers did not know any detection method for PBW.

The knowledge of the farmers on how PBW causing bacteria ( $R$. solanacearum) are spread in their farms varied among districts (Table S2). Sharing farm tools followed by contact with infected plants and tubers were the commonly known modes of spread for $R$. solanacearum, mentioned by 54 and $48 \%$ of the farmers respectively (Table S2). Farm tools were mentioned by more than $33 \%$ of the farmers in all districts, but in Rwamagana, Kayonza and Gicumbi districts, this mode of spread was known by at least $67 \%$ of the farmers. Over $60 \%$ of the farmers in the major potato growing districts mentioned contact with infected plants or tubers as a way of spreading $R$. solanacearum and in total $48 \%$ of the surveyed farmers knew this mechanism. Poor or no crop rotation was mentioned mainly in Rulindo (40\%) and Gicumbi $(67 \%)$ as a spread mechanism of $R$. solanacearum. Spread by wind was mentioned by some farmers in the East (Rwamagana, Kayonza and Gicumbi districts) but this could be mythical because so far $R$. solanacearum is not known as an airborne pathogen (Champoiseau 2008). Spread by rainsplash was known in Nyabihu $(53 \%)$ and Musanze (33\%) districts. About one third of the farmers in Huye and Nyamagabe were ignorant of the dispersal mechanisms of PBW. Overall $18 \%$ of the farmers were not aware of any PBW spread mechanisms and fewer than $50 \%$ farmers were aware of the major spread mechanisms of $R$. solanacearum i.e. infected seeds, soils, plants and tubers (Table 7).

Table 4 Factors used in logistic regression analysis of risk incidence and severity of potato bacterial wilt and likelihood ratio test (LRT) for each factor when entered first and last into the model $^{\mathrm{a}}$

\begin{tabular}{|c|c|c|c|c|c|c|c|c|c|}
\hline \multirow[t]{3}{*}{ Risk factors } & \multirow[t]{3}{*}{ DF } & \multicolumn{4}{|c|}{ PBW Incidence } & \multicolumn{4}{|c|}{ PBW Severity } \\
\hline & & \multicolumn{2}{|c|}{ Variables entered first } & \multicolumn{2}{|c|}{ Variables entered last } & \multicolumn{2}{|c|}{ Variables entered first } & \multicolumn{2}{|c|}{ Variables entered last } \\
\hline & & $\mathrm{DR}$ & $\operatorname{Pr}>x^{2}$ & $\mathrm{DR}$ & $\operatorname{Pr}>x^{2}$ & $\mathrm{DR}$ & $\operatorname{Pr}>x^{2}$ & $\mathrm{DR}$ & $\operatorname{Pr}>x^{2}$ \\
\hline Altitude & 1 & 46.99 & 0.0001 & 22.16 & 0.0001 & 36.28 & 0.0001 & 16.03 & 0.0001 \\
\hline Cropping systems & 2 & 46.59 & 0.0001 & 8.83 & 0.012 & 47.27 & 0.0001 & 10.41 & 0.005 \\
\hline Grown varieties & 2 & 47.34 & 0.0001 & 4.67 & 0.096 & 45.44 & 0.0001 & 0.39 & 0.823 \\
\hline Source of seeds & 4 & 64.57 & 0.0001 & 7.99 & 0.090 & 60.07 & 0.0001 & 6.69 & 0.153 \\
\hline Crop density & 1 & 62.50 & 0.0001 & 25.87 & 0.0001 & 44.23 & 0.0001 & 4.27 & 0.038 \\
\hline Share farm tools & 1 & 37.70 & 0.0001 & 17.71 & 0.0001 & 38.42 & 0.0001 & 12.09 & 0.0005 \\
\hline
\end{tabular}

${ }^{a} P B W$, potato bacterial wilt; $D F$, degree of freedom; $D R$, deviance reduction; $P r$, probability of a $\chi^{2}$ value exceeding the deviance reduction 
Table 5 Analysis of deviance, natural logarithms of odds ratio and standard error of added variables in the reduced model analysing potato bacterial wilt incidence in Rwanda ${ }^{\mathrm{a}}$

\begin{tabular}{|c|c|c|c|c|c|c|c|c|}
\hline \multirow[t]{2}{*}{ Risk factors ${ }^{\mathrm{b}}$} & \multirow[t]{2}{*}{ Residual deviance } & \multirow[t]{2}{*}{$\mathrm{DF}$} & \multicolumn{2}{|l|}{ LRT } & \multirow[t]{2}{*}{ Categories } & \multirow{2}{*}{$\begin{array}{l}\text { Estimates }^{c} \\
\text { Log e (odds ratio) }\end{array}$} & \multirow[t]{2}{*}{ SE } & \multirow[t]{2}{*}{ Odds ratio } \\
\hline & & & DR & $\operatorname{Pr}>\chi^{2}$ & & & & \\
\hline Intercept & 164.76 & & & & & 4.56 & 1.43 & 1 \\
\hline Altitude (masl) & 118.87 & 1 & 45.89 & $1.25 \mathrm{E}^{-11}$ & $\begin{array}{l}\text { High } \\
\text { Medium }\end{array}$ & $\begin{array}{l}-4.93 \\
0^{\mathrm{d}}\end{array}$ & $\begin{array}{l}1.28 \\
-\end{array}$ & $\begin{array}{l}0.01 \\
1\end{array}$ \\
\hline Cropping systems & 79.94 & 2 & 38.93 & $3.51 \mathrm{E}^{-09}$ & $\begin{array}{l}\text { Rotation } \\
\text { Intercropping } \\
\text { Monocropping }\end{array}$ & $\begin{array}{l}-2.81 \\
-0.64 \\
0^{\mathrm{d}}\end{array}$ & $\begin{array}{l}1.05 \\
1.35 \\
-\end{array}$ & $\begin{array}{l}0.06 \\
0.53 \\
1\end{array}$ \\
\hline Crop density & 54.58 & 1 & 25.36 & $4.76 \mathrm{E}^{-07}$ & $\begin{array}{l}\text { Close } \\
\text { Wide }\end{array}$ & $\begin{array}{l}0^{\mathrm{d}} \\
-3.86\end{array}$ & $\begin{array}{l}- \\
1.01\end{array}$ & $\begin{array}{l}1 \\
0.02\end{array}$ \\
\hline Share farm tools & 40.55 & 1 & 14.03 & 0.00018 & $\begin{array}{l}\text { No } \\
\text { Yes }\end{array}$ & $\begin{array}{l}0^{\mathrm{d}} \\
3.35\end{array}$ & $\begin{array}{l}- \\
1.07\end{array}$ & $\begin{array}{l}1 \\
28.6\end{array}$ \\
\hline
\end{tabular}

${ }^{\text {a }} D F$, degree of freedom; $L R T$, likelihood ratio test; $D R$, deviance reduction; $P r$, probability of a $\chi 2$ value exceeding the deviance reduction; $S E$, standard errors

${ }^{\mathrm{b}}$ Terms are added sequentially from first to last in order of presentation in the table

${ }^{c}$ Estimates are from the model with all independent variables added

${ }^{\mathrm{d}}$ The reference category

\subsection{Farmers awareness and practice of PBW management methods}

Farmers' practices of different PBW management methods varied in the surveyed districts (Table S3) and in general they exceeded the farmers' level of awareness in this aspect (Table S2). All farmers in all districts reported that they planted healthy seeds while only $19 \%$ were aware that planting healthy seeds contributed to PBW management. Most farmers (69\%) in the surveyed districts reported that they grow potatoes in soil with no previous PBW infestation and only $35 \%$ farmers made ridges to drain rain water, whereas none of the farmers knew that these practices could manage PBW. A majority of farmers $(90 \%)$ in all the districts uprooted infected potatoes and the same proportion of farmers was aware that this practice helps to control PBW. But only $33 \%$ farmers removed volunteers and plant debris from their potato farms while none of the farmers was aware of this practice as a PBW control method.

About $48 \%$ of farmers in all districts did not share farm tools or use their own tools in someone else's farm, but only $23 \%$ were aware that this practice reduces the risks of spreading PBW. More than $70 \%$ of the farmers in Kayonza and Rwamagana districts did not share farm tools compared to fewer than $40 \%$ in the other districts. Only $20 \%$ of all the farmers planted resistant

Table 6 Analysis of deviance, natural logarithms of odds ratio and standard errors of added variables in the reduced model analysing potato bacterial wilt severity in Rwanda ${ }^{a}$

\begin{tabular}{|c|c|c|c|c|c|c|c|c|}
\hline \multirow[t]{2}{*}{ Risk factors ${ }^{\mathrm{b}}$} & \multirow[t]{2}{*}{ Residual deviance } & \multirow[t]{2}{*}{$\mathrm{DF}$} & \multicolumn{2}{|l|}{ LRT } & \multirow[t]{2}{*}{ Categories } & \multirow{2}{*}{$\begin{array}{l}\text { Estimates }^{\mathrm{c}} \\
\text { Log e (odds ratio) }\end{array}$} & \multirow[t]{2}{*}{ SE } & \multirow[t]{2}{*}{ Odds ratio } \\
\hline & & & DR & $\operatorname{Pr}>x^{2}$ & & & & \\
\hline Intercept & 162.53 & & & & & -1.49 & 0.99 & 0.23 \\
\hline \multirow[t]{2}{*}{ Altitude } & 124.60 & 1 & 22.51 & 0.0001 & High & $0^{\mathrm{d}}$ & _ & 1 \\
\hline & & & & & Medium & 3.27 & 0.85 & 26.4 \\
\hline \multirow[t]{3}{*}{ Cropping system } & 83.09 & 2 & 16.90 & 0.0002 & Mono & $0^{\mathrm{d}}$ & _ & 1 \\
\hline & & & & & Mixed & 0.06 & 1.08 & 1.06 \\
\hline & & & & & Rotation & -2.76 & 0.84 & 0.06 \\
\hline \multirow[t]{2}{*}{ Crop density } & 73.44 & 1 & 6.10 & 0.013 & Close & $0^{\mathrm{d}}$ & _- & 1 \\
\hline & & & & & Wide & -1.59 & 0.66 & 0.20 \\
\hline \multirow[t]{2}{*}{ Sharing farm tools } & 61.03 & 1 & 12.41 & 0.0004 & No & $0^{\mathrm{d}}$ & _ & 1 \\
\hline & & & & & Yes & 2.70 & 0.87 & 14.9 \\
\hline
\end{tabular}

${ }^{\text {a }} D F$, degree of freedom; $L R T$, likelihood ratio test; $D R$, deviance reduction; $P r$, probability of a $\chi 2$ value exceeding the deviance reduction; $S E$, standard errors

b Terms are added sequentially from first to last in order of presentation in the table

${ }^{c}$ Estimates are from the model with all independent variable added

d The reference category 
Fig. 3 Symptoms of potato bacterial wilt. A: wilting symptoms in a potato field in Huye district, B: a circle with ooze in early infected tubers, $\mathrm{C}$ : rotting of tubers and ooze coming from the tuber eyes, D: infected tubers can be discoloured inside and exude a bad smell
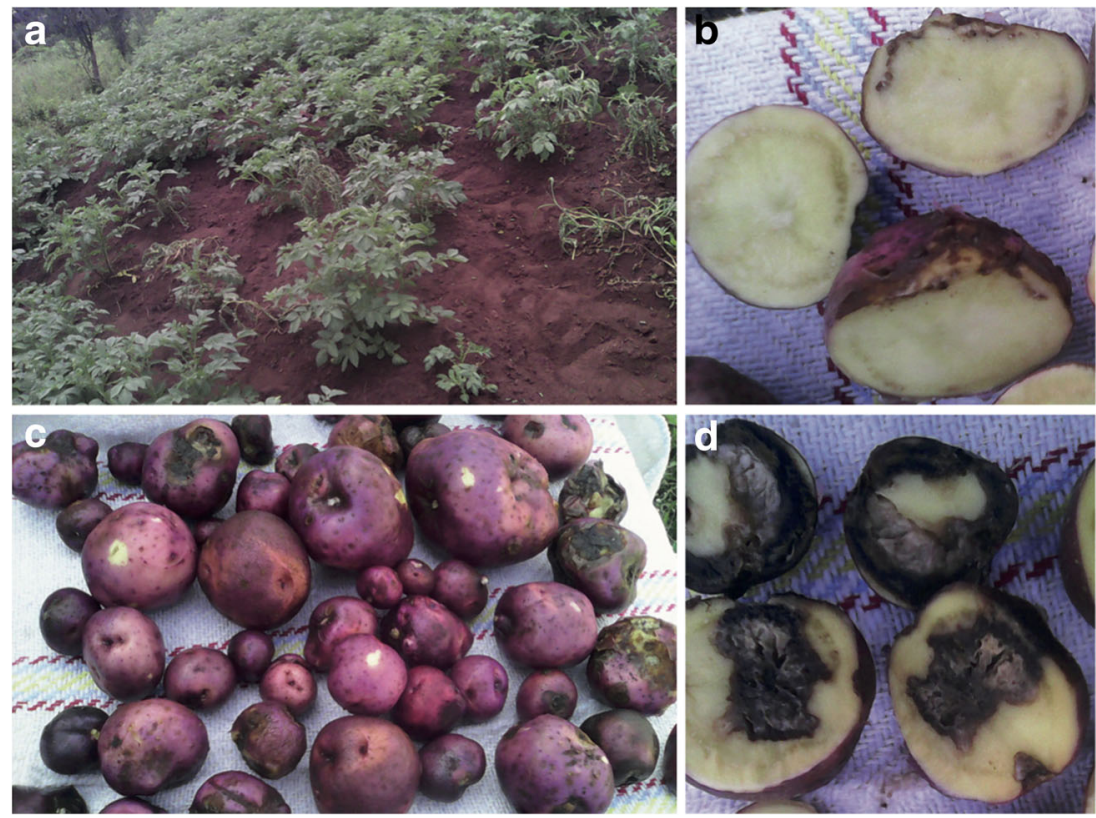

or tolerant varieties and only $7 \%$ were aware of this as a management method for PBW. About $43 \%$ of the farmers in the surveyed districts answered that they did not exchange seed tubers with fellow farmers while none of the farmers was aware of this method to control PBW. Some farmers (7\%) were aware that sterilization of farm tools could manage PBW but none of them were practicing the method. Only $24 \%$ of all farmers were aware that rotation with non-host crops is a PBW management method while $57 \%$ of the farmers practiced the method. This practice was predominant in the northern highland districts (73-100\%) but not in the south and eastern districts $(20-47 \%)$. The rotational sequences of potato in most of the surveyed districts were dominated by one season rotation with maize or wheat (Fig. 4). Other crops rotated with potato were cassava, sorghum, beans, peas, soybeans, pyrethrum, carrots, eggplants and cabbages. Only $3 \%$ of the farmers in all the surveyed districts did not know about any PBW disease management strategy.

\subsection{Ranking source of information on PBW detection, spread and management}

The farmers were given a list of 15 possible sources of information and were asked to rank their information sources through

Table 7 Farmers' awareness of major spread mechanisms for Ralstonia solanacearum $(\mathrm{n}=120)$

\begin{tabular}{ll} 
Spread mechanisms & Respondents (\%) \\
\hline Infected plants or tubers & 47.5 \\
Infected seeds & 35.0 \\
Infected tools & 54.2 \\
Infested soils & 20.0 \\
\hline
\end{tabular}

which they had learned about detection, control and modes of spread of PBW (Tables S4). The majority of the farmers obtained their knowledge about PBW detection, spread and control from their fellow farmers $(83 \%, 77 \%$ and $67 \%$ respectively). About 36 to $43 \%$ of all farmers obtained information from their parents and relatives and only a few of them $(<40 \%)$ received information from agronomists, extentionists, $\mathrm{RAB}$ scientists or researchers (Table $\mathrm{S} 4$ ). The role of agronomists was more important in the major potato growing districts compared to minor growing districts and MINAGRI staff were mentioned by only a few farmers in major potato growing districts. Extension officers and RAB scientists were important in disseminating information on PBW in the southern and northern districts (Huye, Nyamagabe, Rulindo, Nyabihu and Musanze). Information gathering on PBW spread through brochures was only mentioned in the Nyamagabe (20\%) and Nyabihu (13\%) districts. Some farmers in Nyamagabe (20\%), Rulindo (13\%), Gicumbi (27\%), Nyabihu (33\%) and Musanze (13\%) received training from IMBARAGA (Rwanda farmers' federation) together with RAB, FAO (Food and Agriculture Organization of the United Nations) and CIP (International Potato Center) staff. In most districts, the information sources such as radio, television, NGOs and newspapers were not mentioned.

\section{Discussion}

PBW disease was present in all the study districts of Rwanda, and most problematic in areas where potato is considered a minor crop. This study shows that incidence and severity of PBW in the surveyed districts could be lowered by applying management methods such as low plant density, intercropping, crop rotation and avoidance of sharing farm tools. Potato 
Fig. 4 Potato rotational sequences mentioned by the farmers in the surveyed districts $(\mathrm{n}=120)$. No rotation = growing potato for three or more consecutive seasons in monoculture

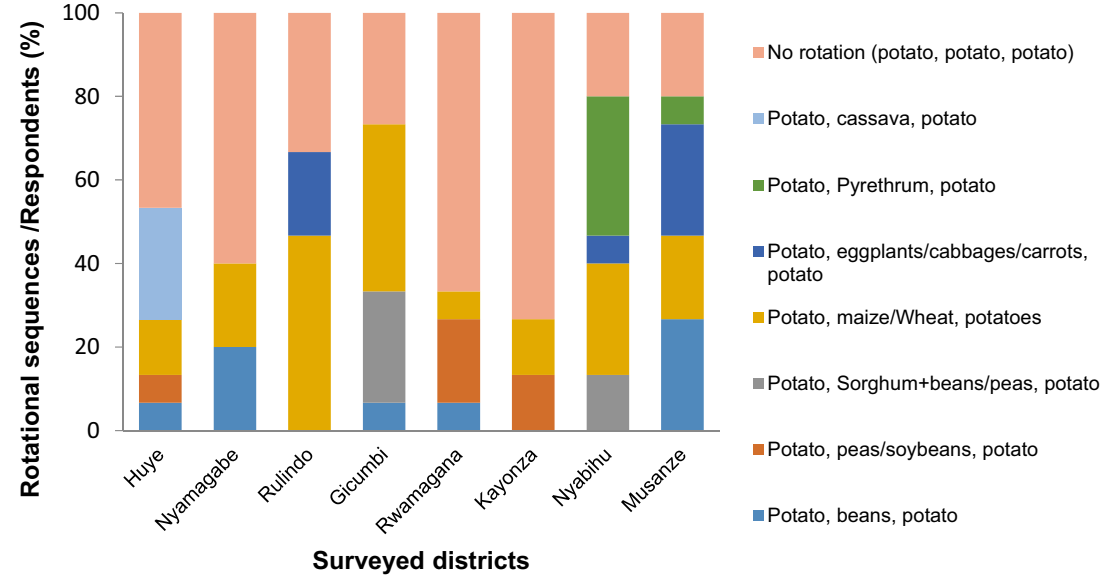

planted at higher altitude had a lower incidence and severity of PBW but this needs to be tested under field conditions in different areas and at different altitudes. Knowledge of PBW detection, spread and management is scarce and haphazard, leading to insufficient management techniques among interviewed farmers from the different districts.

Possible explanations of the presence and widespread distribution of PBW in all study districts may be that PBW has been present in Rwanda for many years (Van der Zaag 1985), the seed system is mainly informal and the movement and exchange of potatoes locally is uncontrolled (USAID 2016). Our findings of higher PBW incidence and severity in minor potato growing areas are consistent with the findings of Scott (1988) who recorded higher PBW incidence in the southern and eastern districts of Rwanda where potato is currently a minor crop. Higher disease incidence and severity in these areas suggest inadequate extension services, targeting non-priority crops and biophysical factors that may not be optimal for potatoes (Verdoodt and Van Ranst 2006). Additionally, in these areas potato is continuously grown to secure food but continuous growing of potatoes in infested soils increases PBW incidence and severity (Muthoni et al. 2014a).

The association of low PBW incidence and severity with high altitude of cropping sites is in agreement with the findings of Ateka et al. (2001), who found a decline of $51 \%$ in bacterial wilt incidence with a rise in altitude from 1800 to 2700 masl. Elphinstone (1996) found that as altitude increased, average temperature and incidence of bacterial wilt decreased. Ciampi et al. (1980) showed that a few strains of race 3 isolated from the highland tropical areas could induce wilting symptoms in potato at $16^{\circ} \mathrm{C}$ while other strains caused symptoms at $20^{\circ} \mathrm{C}$ and above. Strains of $R$. solanacearum adapted to warmer temperatures lose their virulence in plants grown at relatively cool temperatures $\left(16{ }^{\circ} \mathrm{C}\right.$ to $20{ }^{\circ} \mathrm{C}$ ) (Milling et al. 2009; Huerta et al. 2015), which is the maximum temperature range in the major potato growing areas of highland Rwanda. However, race 3 biovar 2 (R3bv2), a known strain causing PBW in Rwanda (He et al. 2012), causes damage in cool climates and is strongly associated with latent infection (French 1994). In this study, the proportion of latent infections of plants in the fields was not assessed.

The finding in this study that crop rotation is highly associated with low incidence and severity of PBW echo earlier studies (Kakuhenzire et al. 2013; Katafiire et al. 2005; Lemaga et al. 2001; Gildemacher et al. 2009; Mwaniki et al. 2017). Rotations including spring onion with barley and wheat reduced PBW disease in Kenya (Mwaniki et al. 2017). In Uganda, rotating potatoes with wheat, sweet potato, maize, millet, carrots, sorghum, or beans reduced wilt incidence and increased yields of potatoes (Katafiire et al. 2005). However, one season without potato, as practiced by the farmers in this study is too short for elimination of the pathogen in infested fields. Gildemacher et al. (2009) recommended a four season rotation (1.5 to 2 years depending on the geographical location) but this is currently impractical regarding the individual farmer's land size and the role of potato for food security in Rwanda.

The reduction in disease incidence by intercropping and wide spacing that we found is due to increased distances between individual potato plants and the presence of the root systems of other plant species between the potato plants (Autrique and Potts 1987). Wide spacing significantly reduced incidence and severity of PBW (Tables 5 and 6). The recommended potato planting density in Rwanda is $30 \mathrm{~cm}$ between plants (pers. communication with RAB staff), but the majority of farmers plant more densely than recommended owing to shortage of land. By increasing the spacing between potato plants through intercropping, incidence of PBW incidence as well as rate of disease development could be significantly reduced (Autrique and Potts 1987).

A large proportion of farmers in this study exchange farm tools (Table S3), probably because they are encouraged to consolidate their land and work together in groups, associations or cooperatives using their own farm tools on different farms (Kathiresan 2012). However, this practice should be accompanied with tool sterilization since the exchange of farm tools 
resulted in higher PBW incidence and severity. It is mainly through PBW infected soil adhering to tools that PBW disease is spread between different fields if tools are not sterilized before and after use in each field. The options for tools sterilization include passing them through a flame or using sodium hypochlorite (household bleach or JIK) (Sharma et al. 2017). But not all farmers can afford sodium hypochlorite and there is lack of knowledge among farmers of the importance of tools sterilization (Table S3). Farmers should be sensitized to the importance of sterilizing tools. Methods for sterilizing tools in a safe and appropriate manner need to be developed.

In both plant and public health epidemiology, the association of diseases and risk factors have been demonstrated (Breslow 1978; Willett 2002; Savary et al. 2011). For instance, analysing risk factors using logistic regression provided estimates of the contribution of climatic years, wheat varieties, and crop management to the likelihood of epidemic occurrence in wheat (Savary et al. 2016). Similarly, Jones et al. (2008) revealed the association between socioeconomic, environmental, and ecological environments and patterns of emerging infectious diseases.

The farmers interviewed were aware that PBW is a major threat to their potato production and ranked it as the major disease constraint (Fig. 2). The reason is that fungicide sprays can be used for late blight control, but no equivalent control measure is available for PBW control. Conversely, previous studies (Bicamumpaka and Haverkort 1983; Devaux et al. 1987; Scott 1988; Muhinyuza et al. 2012) reported late blight as the major potato disease constraint in Rwanda. Most of the farmers in this study identified PBW symptoms mainly based on wilting plants and rotting tubers. However, their knowledge about PBW spread and management was scarce in all districts (Table S2). These findings are similar to results of a survey performed in Kenya by Kwambai et al. (2011), where the farmers identified PBW by looking for wilting plants and rotting tubers but their knowledge on the causal organism, mode of spread and management of PBW was limited. Limited PBW knowledge by the farmers in Rwanda is probably due to the inaccessibility of accurate information since most of the farmers received their information about PBW mainly from their fellow farmers and relatives.

Some of the farmers interviewed were aware of different PBW management methods. However, the awareness of management methods did not always agree with their attitudes to managing the disease. Uprooting of infected potato plants was a well known method and practiced by the majority of farmers, indicating the willingness of the farmers to control PBW. However, only about half of the farmers who uprooted infected plants removed the debris from their potato fields, while others left them in the field (Table S3). Kwambai et al. (2011) reported that poor disposal of the uprooted material aggravated the spread and survival of the pathogen even in rotated crops. The recommended practice is to collect and bury potatoes and other crop residues (Priou et al. 1999). On the other hand, many farmers practice some PBW management methods unknowingly. One example is the practice of crop rotation as a means of controlling PBW. This shows that some farmers practice rotations for other purposes such as improvement of soil fertility (Ahmad et al. 2014). A third of surveyed farmers, making furrows to drain water, were unaware of the importance and potential of this practice in reducing PBW infestation. All the interviewed farmers reported that they planted healthy looking seeds and $69 \%$ planted them in soils with no previous PBW infestation. However, $86 \%$ farms in this study had PBW infestation in their fields (data not shown). This points to the farmers' difficulties in detecting soil infestation or latent infections in seed tubers (Chindi and Kassa 2013). There are also farmers who are aware of control methods such as sterilization of farm tools but do not practice them.

PBW distribution in Rwanda reflects the knowledge and attitudes of the farmers. In districts with high PBW incidence and severity, awareness and practice of PBW management methods is lower, explaining a possible continuity of PBW dissemination instead of containment. This could be attributed to the fact that the role of extension officers, agriculturists, and RAB scientists is minor in districts where potato is not a priority crop, resulting in high PBW incidence and severity. Farmers could therefore reduce PBW incidence if they were equipped with proper knowledge. Approaches such as Farmer Field schools and Farmer Promoters, already in place in Rwanda (Anonymous 2016), could potentially help in advising farmers on the management of PBW if they were equipped with appropriate knowledge of detection, spread and management of PBW. Additionally, mass media such as radio and television were not used to distribute PBW information to the farmers. Considering the role of potato in food security and the impact of PBW, these channels should be considered for dissemination of information to all farmers on measures to control PBW in already infested potato farming communities.

Several studies demonstrated inconsistency between farmers' knowledge and attitudes towards the management of plant diseases. Tomato growing farmers in India were aware of the symptoms of tomato leaf curl but only a few farmers knew that the disease was transmitted by white flies (Nagaraju et al. 2002). Similarly Oo et al. (2012) observed that the farmers in Myanmar did not know which pests and diseases were affecting their crops, most of them had not heard about integrated pest management (IPM) and relied on pesticide applications to manage the diseases and pests. In subSaharan Africa, Adam et al. (2015) found that farmers could recognize unhealthy plants, but they had difficulties in identifying diseases. Some farmers used management practices provided by plant pathologists while others lacked knowledge and used inefficient methods (Adam et al. 2015). Operation of disease management practices is determined by the famers'level of knowledge and perception of disease. 
Potato is an important crop for food security worldwide (Lutaladio and Castaldi 2009; Devaux et al. 2014) and remains one of the predominant food crops in Rwanda. This study indicates that about 50 to $60 \%$ of total cultivated land was under potato cultivation, reflecting the importance farmers attach to the crop. In high potato producing areas (for instance Nyabihu, Musanze and Gicumbi districts), the crop has predominantly become an income earner, allowing substantial income and enabling farmers to cater for family needs and wellbeing (Lutaladio and Castaldi 2009). However, the presence of PBW in all the surveyed areas indicates the potential threat that the disease poses to the potato industry if sustainable management strategies are not practiced.

\section{Conclusion}

This study aimed at assessing PBW distribution, risk factors, farmers' knowledge and attitudes in Rwanda. Considering the role of potato in food security and income generation for potato farmers, the presence of PBW in all the surveyed districts of Rwanda needs special attention. We show that agricultural development efforts to limit the impact of PBW should focus on improving farmer adoption of best practices: increasing spacing or decreasing planting density, practicing crop rotation, including other non-host crops in potato fields and sterilizing tools. These steps would help to increase yield and improve food security for smallholder farmers in Rwanda. Potato farmers need to be informed of the detection, spread and management of PBW because such knowledge currently is acquired mainly via other farmers or relatives and may be incorrect. Ultimately, controlled movement of potatoes locally and within and outside the country and the ability to detect latent infection in seed and ware potatoes are also required to reduce the incidence and severity of the disease.

Acknowledgements This work was funded by the Swedish International Development Cooperation Agency (Sida) through the UR-Sweden Programme for Research, Higher Education and Institutional Advancement. We are grateful to the University of Rwanda (UR), the Swedish University of Agricultural Sciences (SLU) and everyone who contributed to this research. We thank the reviewers for providing comments to improve the manuscript.

\section{Compliance with ethical standards}

Conflict of interest Authors declare that they have no conflict of interest.

Open Access This article is distributed under the terms of the Creative Commons Attribution 4.0 International License (http:// creativecommons.org/licenses/by/4.0/), which permits unrestricted use, distribution, and reproduction in any medium, provided you give appropriate credit to the original author(s) and the source, provide a link to the Creative Commons license, and indicate if changes were made.

\section{References}

Adam, R. I., Sindi, K., \& Badstue, L. (2015). Farmers' knowledge, perceptions and management of diseases affecting sweet potatoes in the Lake Victoria zone region, Tanzania. Crop Protection, 72, 97-107. https://doi.org/10.1016/j.cropro.2015.02.010.

Ahmad, W., Shah, Z., Jamal, M., \& Shah, K. A. (2014). Recovery of organic fertility in degraded soil through fertilization and crop rotation. Journal of the Saudi Society of Agricultural Sciences, 13(2), 92-99. https://doi.org/10.1016/j.jssas.2013.01.007.

Ali, D. A., \& Deininger, K. (2015). Is there a farm size-productivity relationship in African agriculture? Evidence from Rwanda. Land Economics, 91(2), 317-343. https://doi.org/10.1596/1813-94506770.

Anonymous (2016). Twigire Muhinzi Reflection Paper (p 16). Kigali, Rwanda: Ministry of Agriculture and Animal Resources of the Republic of Rwanda \& The Belgian Development Agency.

Ateka, E., Mwang'ombe, A. W., \& Kimenju, J. (2001). Reaction of potato cultivars to Ralstonia solanacearum in Kenya. African Crop Science Journal, 9(1), 251-256. https://doi.org/10.4314/ acsj.v9i1.27646.

Autrique, A., \& Potts, M. (1987). The influence of mixed cropping on the control of potato bacterial wilt (Pseudomonas solanacearum). Annals of Applied Biology, 111(1), 125-133.

Bennett, B. C. (2010). Plants as food. In B. Bennett (Ed.), Economic botany: Encyclopedia of life support systems (EOLSS). Eolss publishers. Oxford, UK: Developed under the Auspices of the UNESCO.

Bicamumpaka, M., \& Haverkort, A. (1983). The PNAP approach to potato development in Rwanda. In Report of a seminar on Agricultural research in Rwanda: Assessment and perspectives, (pp. 159-164).

Bicamumpaka, M., \& Devaux, A. (1984). Programme de sélection au Rwanda pour l'obtention de variétés résistantes au mildiou (Phytophthora infestans) et à la bactériose (Pseudomonas solanacearum). In Abstracts 9th Triennial Conference EAPR, 330-331.

Birch, P. R., Bryan, G., Fenton, B., Gilroy, E. M., Hein, I., Jones, J. T., \& Toth, I. K. (2012). Crops that feed the world 8: Potato: Are the trends of increased global production sustainable? Food Security, 4(4), 477-508. https://doi.org/10.1007/s12571-012-0220-1.

Breslow, L. (1978). Risk factor intervention for health maintenance. Science, 200, 908-912.

Callaway, E. (2016). Devastating wheat fungus appears in Asia for first time. Nature, 532, 421-422. https://doi.org/10.1038/532421a.

Cellier, G., \& Prior, P. (2010). Deciphering phenotypic diversity of Ralstonia solanacearum strains pathogenic to potato. Phytopathology, 100(11), 1250-1261. https://doi.org/10.1094/ PHYTO-02-10-0059.

Champoiseau, P. G. (2008). Ralstonia solanacearum race 3 biovar 2 . United states department of agriculture-national research initiative program. https://plantpath.ifas.ufl.edu/rsol/ RalstoniaPublications_PDF/RsolanacearumR3b2_PDF.pdf. Accessed on $19^{\text {th }}$ June 2018 .

Champoiseau, P. G., Jones, J. B., \& Allen, C. (2009). Ralstonia solanacearum race 3 biovar 2 causes tropical losses and temperate anxieties. Plant Health Progress, 10, 1-10. https://doi.org/10.1094/ PHP-2009-0313-01-RV.

Champoiseau, P., Jones, J., Momol, T., Pingsheng, J., Allen, C., Norman, D. J., \& Caldwell, K. (2010). Ralstonia solanacearum race 3 biovar 2 causing brown rot of potato bacterial wilt of tomato and southern wilt of geranium. Madison: American Phytopathological Society.

Chindi, A., \& Kassa, B. (2013). Seed Tuber Cycle and Latent Infection for the Spread of Potato Bacterial Wilt Ralstonia solanacearum 
(Smith) a Threat for Seed Production in Ethiopia. Asian Journal of Plant Pathology, 7, 74-83.

Ciampi, L., Sequeira, L., \& French, E. (1980). Latent infection of potato tubers by Pseudomonas solanacearum. American Journal of Potato Research, 57(8), 377-386.

Creswell, J. W. (2002). Educational research: Planning, conducting, and evaluating quantitative. Upper Saddle River, NJ: Prentice Hall.

De Mendiburu, F. (2015). Statistical procedures for agricultural research $\mathrm{R}$ package agricolae. Comprehensive R Archive Network, 1, 2-3.

Devaux, A., Michelante, D., \& Bicamumpaka, M. (1987). Combination of rotation and resistance to control bacterial wilt (Pseudomonas solanacearum) in Rwanda. European Association Potato Research. In X Triennial Conference Abstracts, (pp. 100-101).

Devaux, A., Kromann, P., \& Ortiz, O. (2014). Potatoes for sustainable global food security. Potato Research, 57(3-4), 185-199.

Elphinstone, J. (1996). Survival and possibilities for extinction of Pseudomonas solanacearum (smith) in cool climates. Potato Research, 39(3), 403-410.

FAO (2008). International year of the potato. Potatoes, nutrition and diets. In FAO factsheets. Rome, Italy: Food and Agriculture Organization of the United States. http://www.fao.org/potato-2008/en/potato/ factsheets.html. Accessed on $15^{\text {th }}$ October, 2017.

FAOSTAT. (2015). FAOSTAT database. Rome, Italy: FAO.

FAO (2017). Plant health and food security. http://www.fao.org/3/ai7829e.pdf. Accessed on 23rd April 2018.

Fegan, M., \& Prior, P. (2005). How complex is the Ralstonia solanacearum species complex. In Bacterial wilt Disease and the Ralstonia solanacearum Species Complex (pp. 449-461). Minnesota: APS Press.

Fininsa, C., \& Yuen, J. (2001). Association of maize rust and leaf blight epidemics with cropping systems in Hararghe highlands. eastern Ethiopia. Crop Protection, 20(8), 669-678.

Flood, J. (2010). The importance of plant health to food security. Food Security, 2(3), 215-231.

French, E. R. (1994). Strategies for integrated control of bacterial wilt of potatoes. In A. C. Hayward \& G. L. Hartman (Eds.), Bacterial wilt: The disease and its causative agent, Pseudomonas solanacearum (pp. 98-113). UK: CAB International.

Fuglie, K. O. (2007). Priorities for potato research in developing countries: Results of a survey. American Journal of Potato Research, 84(5), 353-365.

Gikunda C. (2015). Researchers partner to eliminate wilt disease as a region's potato yields decline. http://www.theeastafrican.co.ke/ news/Researchers-partner-to-eliminate-bacterial-wilt-disease/2558 2816554-hu1ib/index.html. Accessed on $20^{\text {th }}$ September 2017.

Gildemacher, P. R., Demo, P., Barker, I., Kaguongo, W., Woldegiorgis, G., Wagoire, W. W., Wakahiu, M., Leeuwis, C., \& Struik, P. C. (2009). A description of seed potato systems in Kenya, Uganda and Ethiopia. American Journal of Potato Research, 86(5), 373 382. https://doi.org/10.1007/s12230-009-9092-0.

Haverkort, A., Bicamumpaka, J., Devaux, A., Munyawera, J., \& Rutayisiri, C. (1984). The impact of selection and multiplication of varieties on national potato production in Rwanda. In 9th Triennial Conference of the European Association for Potato Research. Interlaken, Switzerland.

He, Z., Larkin, R., \& Honeycutt, W. (2012). Sustainable potato production: Global case studies. Springer Science \& Business Media.

Horita, M., \& Tsuchiya, K. (2001). Genetic diversity of Japanese strains of Ralstonia solanacearum. Phytopathology, 91(4), 399-407.

Huerta, A. I., Milling, A., \& Allen, C. (2015). Tropical strains of Ralstonia solanacearum outcompete race 3 biovar 2 strains at lowland tropical temperatures. Applied and Environmental Microbiology, 81(10), 3542-3551. https://doi.org/10.1128/AEM. 04123-14.
Jones, K. E., Patel, N. G., Levy, M. A., Storeygard, A., Balk, D., Gittleman, J. L., \& Daszak, P. (2008). Global trends in emerging infectious diseases. Nature, 451, 990-993.

Kakuhenzire, R., Lemaga, B., Kashaija, I., Ortiz, O., \& Mateeka, B. (2013). Effect of Crotalaria falcata in crop rotation and fallowing on potato bacterial wilt incidence, disease severity and latent infection in tubers and field soil. Biopesticides International, 9(2), 182-194.

Katafiire, M., Adipala, E., Lemaga, B., Olanya, M., El-Bedewy, R., \& Ewell, P. (2005). Management of bacterial wilt of potato using oneseason rotation crops in southwestern Uganda. In Bacterial wilt disease and the Ralstonia solanacearum species complex (pp. 197-204). Minnesota: American Phytopathological Society Press.

Kathiresan, A. (2011). Strategies for Sustainable Crop Intensification in Rwanda: Shifting focus from producing enough to producing surplus. Kigali, Rwanda: Ministry of Agriculture and Animal Resources.

Kathiresan, A. (2012). Farm land use consolidation in Rwanda. Kigali, Rwanda: Ministry of Agriculture and Animal Resources.

Kurabachew, H., \& Ayana, G. (2017). Bacterial wilt caused by Ralstonia solanacearum in Ethiopia: Status and management approaches: A review. International Journal of Phytopathology, 5(3), 107-119.

Kwambai, T., Omunyin, M., Okalebo, J., Kinyua, Z., \& Gildemacher, P. (2011). Assessment of potato bacterial wilt disease status in north Rift Valley of Kenya: A survey. In innovations as key to the green revolution in Africa (pp. 449-456): Springer, Assessment of Potato Bacterial Wilt Disease Status in North Rift Valley of Kenya: A Survey.

Lemaga, B., Kakuhenzire, R., Kassa, B., Ewell, P., Priou, S., Allen, C., et al. (2005). Integrated control of potato bacterial wilt in eastern Africa: The experience of African highlands initiative. In Bacterial wilt disease and the Ralstonia solanacearum species complex (pp. 145-157). Minnesota: American Phytopathological Society Press.

Lemaga, B., Kanzikwera, R., Kakuhenzire, R., Hakiza, J., \& Manzi, G. (2001). The effect of crop rotation on bacterial wilt incidence and potato tuber yield. African Crop Science Journal, 9(1), 257-266.

Lutaladio, N., \& Castaldi, L. (2009). Potato: The hidden treasure. Journal of Food Composition and Analysis, 22(6), 491-493.

Martin, C., \& French, E. R. (1985). Bacterial wilt of potato. Lima, Peru: International Potato Center.

McCullagh, P., \& Nelder, J. (1989). Log-linear models. In Generalized linear models (pp. 193-244): Springer.

Meijer, S. S., Catacutan, D., Ajayi, O. C., Sileshi, G. W., \& Nieuwenhuis, M. (2015). The role of knowledge, attitudes and perceptions in the uptake of agricultural and agroforestry innovations among smallholder farmers in sub-Saharan Africa. International Journal of Agricultural Sustainability, 13(1), 40-54.

Milling, A., Meng, F., Denny, T. P., \& Allen, C. (2009). Interactions with hosts at cool temperatures, not cold tolerance, explain the unique epidemiology of Ralstonia solanacearum race 3 biovar 2 . Phytopathology, 99(10), 1127-1134. https://doi.org/10.1094/ PHYTO-99-10-1127.

MINAGRI (2014). Annual Report FY 2013-2014. Kigali, Rwanda: Ministry of Agriculture and Animal Resources.

Mpyisi, E., Weber, M., Shingiro, E., \& Loveridge, S. (2003). Changes in Allocation of Land holdings, Production and Farm Size in the Rwandan Smallholder Sector over the period 1984/1990 to 2002. Agricultural Policy Synthesis, 6E.

Muhinyuza, J. B., Shimelis, H., Melis, R., Sibiya, J., \& Nzaramba, M. N. (2012). Participatory assessment of potato production constraints and trait preferences in potato cultivar development in Rwanda. International Journal of Development and Sustainability, 1(2), $358-380$.

Munyemana, A., \& Oppen, M. (2000). La pomme de terre au Rwanda: Une analyse d'une filiere a hautes potentialites. Lima, Peru: International Potato Center. 
Muthoni, J., Shimelis, H., \& Melis, R. (2012). Management of bacterial wilt Rhalstonia solanacearum Yabuuchi et al., 1995 of potatoes: Opportunity for host resistance in Kenya. Journal of Agricultural Science (Toronto), 4(9), 64-78. https://doi.org/10.5539/jas. v4n9p64.

Muthoni, J. J., Shimelis, H., \& Melis, R. (2013). Potato production in Kenya: Farming systems and production constraints. Journal of Agricultural Science, 5(5), 182-187. https://doi.org/10.5539/jas.v5n5p182.

Muthoni, J., Kabira, J., Shimelis, H., \& Melis, R. (2014a). Spread of bacterial wilt disease of potatoes in Kenya: Who is to blame? International Journal of Horticulture, 4(3), 10-15. https://doi.org/ 10.5376/ijh.2014.04.0003.

Muthoni, J., Shimelis, H., Melis, R., \& Kinyua, Z. (2014). Response of potato genotypes to bacterial wilt caused by Ralstonia solanacearum (smith) (Yabuuchi et al.) in the tropical highlands. American Journal of Potato Research, 91(2), 215-232. https://doi.org/10.1007/ s12230-013-9340-1.

Mwaniki, P., Wagara, I., Birech, R., Kinyua, Z., Schulte-Geldermann, E., $\&$ Freyer, B. (2017). Impact of crop rotation sequences on potato in fields inoculated with bacterial wilt caused by Ralstonia solanacearum. African Journal of Agricultural Research, 12(14), 1226-1235. https://doi.org/10.5897/AJAR2016.11769.

Mwankemwa, Z. (2015). Occurrence and distribution of potato bacterial wilt disease and variability of its causal agent in southern highlands of Tanzania. Doctoral dissertation, Sokoine University of Agriculture. http://www.suaire.suanet.ac.tz:8080/xmlui/handle/ 123456789/1371. Accessed on 25 April 2018.

Nagaraju, N., Venkatesh, H. M., Warburton, H., Muniyappa, V., Chancellor, T. C. B., \& Colvin, J. (2002). Farmers' perceptions and practices for managing tomato leaf curl virus disease in southern India. International journal of pest management, 48(4), 333-338.

Oo, M. L., Yabe, M., \& Khai, H. V. (2012). Farmers' perception, knowledge and pesticide usage practices: A case study of tomato production in inlay Lake. Myanmar. Journal of the Faculty of Agriculture, Kyushu University, 57(1), 327-331.

Pasiecznik, N., Smith, I., Watson, G., Brunt, A., Ritchie, B., \& Charles, L. (2005). CABI/EPPO distribution maps of plant pests and plant diseases and their important role in plant quarantine. Eppo Bulletin, 35(1), 1-7.

Priou, S., Aley, P., Chujoy, E., Lemaga, B., French, E., \& French, E. (1999). Integrated control of bacterial wilt of potato. In CIP Slide Training Series. Lima, Peru. International Potato Center.

REMA (2011). The National Integrated Pest Management (IPM) Framework for Rwanda. Rwanda Environmental Management Authority. Kigali, Rwanda. www.rema.gov.rw/rema_doc/LVEMP/ IPM Latest\%20Version-2.pdf. Accessed on $24^{\text {th }}$ May 2018.

RMA. (2015). Rwanda climate data. Kigali, Rwanda: Rwanda Meteorology Agency.

Rusuku, G., Buruchara, R. A., Gatabazi, M., \& Pastor-Corrales, M. A. (1997). Occurrence and distribution in Rwanda of soilborne fungi pathogenic to the common bean. Plant Disease, 81(5), 445-449.

Savary, S., Mila, A., Willocquet, L., Esker, P. D., Carisse, O., \& McRoberts, N. (2011). Risk factors for crop health under global change and agricultural shifts: A framework of analyses using rice in tropical and subtropical Asia as a model. Phytopathology, 101(6), 696-709.

Savary, S., Ficke, A., Aubertot, J. N., \& Hollier, C. (2012). Crop losses due to diseases and their implications for global food production losses and food security. Food Security, 4, 519-537. https://doi. org/10.1007/s12571-012-0200-5.

Savary, S., Jouanin, C., Félix, I., Gourdain, E., Piraux, F., Willocquet, L., \& Brun, F. (2016). Assessing plant health in a network of experiments on hardy winter wheat varieties in France: Multivariate and risk factor analyses. European Journal of Plant Pathology, 146(4), $757-778$.

Scott, G. J. (1988). Potatoes in Central Africa: A Study of Burundi, Rwanda and Zaire. Lima. In Peru: International Potato Center.
Sharma, K., Shawkat, B., Miethbauer, T. \& Schulte-Geldermann, E. (2017). Strategies for Bacterial Wilt (Ralstonia solanacearum) Management in Potato Field: Farmers' Guide. https:// nkxms1019hx1 xmtstxk3k9sko-wpengine.netdna-ssl.com/ wpcontent/uploads/2017/05/CIP-BW-Strategies-2017.pdf. Accessed 7 November 2017.

Sreenivasaprasad, S., \& Johnson, R. (2001). Major fungal diseases of Rice: Recent advances. Netherlands: Kluwer Academic Publishes.

Stansbury, C., McKirdy, S., Mackie, A., \& Power, G. (2001). Bacterial wilt Ralstonia solanacearum-race 3, exotic threat to western Australia. Fact Sheet ISSN, 1443-7783.

Strange RN. (2003). Introduction to plant pathology. Wiley, Chichester, UK. 464 pp.

Strange, R. N., \& Scott, P. R. (2005). Plant disease: A threat to global food security. Annual Review of Phytopathology, 43, 83-11. https://doi. org/10.1146/annurev.phyto.43.113004.133839.

R Core Team. (2016). $R$ : A language and environment for statistical computing. Vienna: R Foundation for Statistical Computing.

USAID (2016) Rwanda early generation seed study country report. http:// www.africaleadftf.org/wp-content/uploads/2016/09/Rwanda-EGSStudy-Final-Report.pdf. Accessed on 26th September 2017.

Van der Zaag, P.(1985). Potato production under Pseudomonas solanacearum conditions: sources and management of planting material. In Disease in Asia and South Pacific: Proceedings of an international workshop (pp. 84-88). Los Banos, Philippines.

Van Elsas, J., Van Overbeek, L., Bailey, M., Schönfeld, J., \& Smalla, K. (2005). Fate of Ralstonia solanacearum biovar 2 as affected by conditions and soil treatments in temperate climate zones: APS press, The American Phytopathological Society.

Verdoodt, A., \& Van Ranst, E. (2006). Environmental assessment tools for multi-scale land resources information systems: A case study of Rwanda. Agriculture, Ecosystems \& Environment, 114(2-4), 170184.

Willett, W. C. (2002). Balancing life-style and genomics research for disease prevention. Science, 296, 695-698.

Yuen, J., Twengström, E., \& Sigvald, R. (1996). Calibration and verification of risk algorithms using logistic regression. European Journal of Plant Pathology, 102(9), 847-854.

Zadoks, J. C. (2008). On the political economy of plant disease epidemics. Capita Selecta in historical epidemiology. Wageningen: Wageningen Academic Publishers.

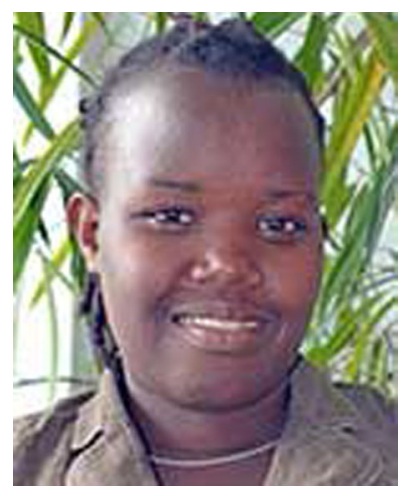

Florence Uwamahoro graduated in Crop production and Horticulture from the National University of Rwanda and holds an MSc in Plant Pathology from the University of Agricultural Sciences (UAS) Bangalore, India. From February 2012, she was an assistant lecturer at the College of Agriculture, Animal Sciences and Veterinary Medicine (CAVM) in the University of Rwanda (UR). Currently, she is pursuing her $\mathrm{PhD}$ studies in the department of Forest Mycology and Plant Pathology at the Swedish University of Agricultural Sciences (SLU). Her PhD research is about the population biology and epidemiology of Ralstonia solanacearum and Xanthomonas campestris $p v$. musacearum causing potato bacterial wilt and banana Xanthomonas wilt, respectively, in Rwanda. 


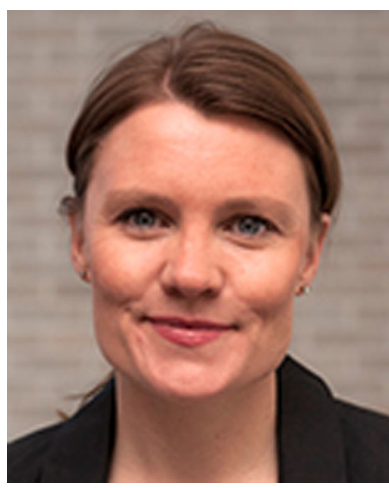

Dr. Anna Berlin received her graduate education in 2012 in the Department of Forest Mycology and Plant Pathology, Swedish University of Agricultural Sciences (SLU), Uppsala. She has an MSc in Agriculture from SLU, Uppsala. Since her PhD, Anna has been working as a researcher in plant pathology. Her primary research interests are population dynamics of plant pathogenic fungi and studying how different fungi are spread in order to understand the epidemiology of various plant diseases.

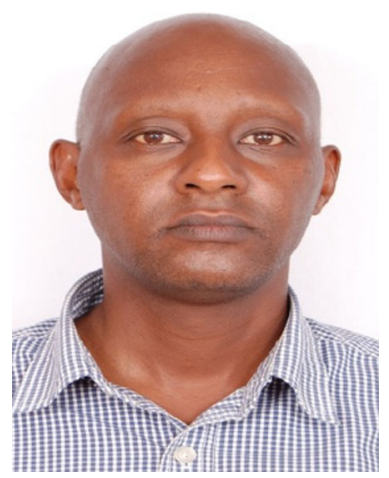

Charles Bucagu is an Associate Professor and Dean of the School of Agriculture and Food Sciences at the University of Rwanda. Charles's research over a decade has focused on smallholder farming systems in Rwanda with particular emphasis on exploring the diversity of mixed agroforestry based farming systems within different agroecological zones and identifying the role of agroforestry in addressing problems related to soil nutrient deficiencies and poor quality of livestock feeds. Particular emphasis is accorded to issues regarding resource use and exploring options for optimizing resource use on farms. In that context, he obtained his $\mathrm{PhD}$ in 2013 in Agroforestry from Wageningen University and has published a number of papers in scientific journals. His teaching and research involves the use of trees and shrubs in particular farming environments and targeting appropriate options for integration in agricultural production systems. He has vast experience in training and student supervision and is involved with a large network of scientists with the view of building partnerships to develop research for impact in rural communities.

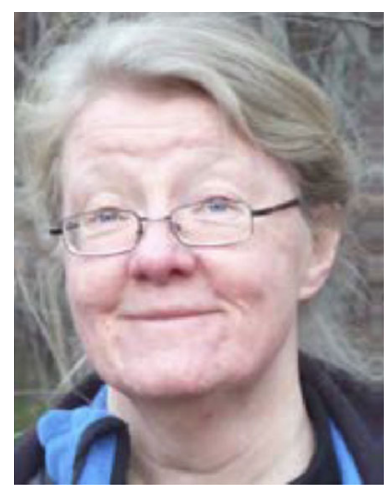

Associate Professor Helena Bylund is a senior researcher at the Department of Ecology, Swedish University of Agricultural Sciences (SLU), Uppsala, Sweden. She has long experience of insect ecological research in mainly northern forests but also agricultural systems in the tropics with focus on population ecology, spatiotemporal population dynamics of insect pests and to some extent biocontrol and risk assessment of insect damage.

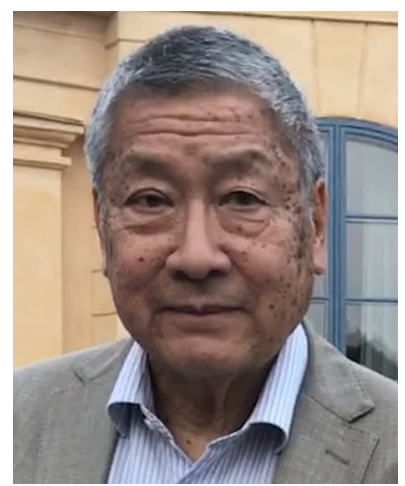

Professor Yuen is an internationally recognized expert in plant pathology, plant disease epidemiology, modelling, and statistics. He has published over 125 research papers, of which over 90 are journal articles or chapters in scholarly books. His research interests include quantitative epidemiology and the population biology of plant pathogens, including Phytophthora infestans and several rusts and other pathogens of small grains. He has used a variety of techniques to study pathogen populations, from molecular markers to a variety of modelling approaches, including process-based simulation models, empirical statistical models, and a number of Bayesian techniques. He was a leader in the use of logistic regression in developing risk algorithms, and was an early proponent of using ROC curves to evaluate the quality of these algorithms. 